\title{
Looking for American Nationhood A Study of James Fenimore Cooper's The Last of the Mohicans
}

\author{
Masoud Farahmandfar \\ Shahid Beheshti University, Iran \\ Gholamreza Samigorganroodi (Corresponding author) \\ Fanshawe College, Canada
}

Received: 13-09-2015

Accepted: 25-10- 2015

Published: 05-01-2016

doi:10.7575/aiac.ijclts.v.4n.1p.4

URL: http://dx.doi.org/10.7575/aiac.ijclts.v.4n.1p.4

\begin{abstract}
James Fenimore Cooper's The Last of the Mohicans can be read as an outline for the contact (or clash) of many diverse cultures. This novel may also be seen as a story of the development of American national-racial identity. The present paper aims at examining Cooper's classic novel in order to reveal the underlying discourse of race and nationhood. The paper will discuss Cooper's idea of historical change and human progress, and will show how the teleological, stage-by-stage passage of history from savagery to civilization, from tribal communities to a unified nation, empowered by cultural appropriation, resulted in the formation of a fresh and inevitably hybrid American national identity.
\end{abstract}

Keywords: Nation, Historical Progress, Race, Hybridity

\section{Introduction}

The interplay between nationalism and exile is like Hegel's dialectic of servant and master, oppositions informing and constituting each other. All nationalisms in their early stages develop from a condition of estrangement.

Edward Said, "Reflections on Exile"

The dawn of the novel is, in many cultures and languages, tied to history. However, historical novel as an independent genre developed during the Romantic period and matured in the nineteenth century as a result of a growing sense of history - that emerged out of the Enlightenment - and nationalism - emerging after the French Revolution. Thus, historical novel, as a hybrid genre, was strengthened by a nationalist impulse to recreate the past and rewrite either the glories of a nation's past or the hardships it has suffered on the path of progress. Therefore, one can claim that historical novel is in one way or another related to the discourse of nationhood. Many great writers have pioneered and developed this genre: Sir Walter Scott (Waverley), Alfred de Vigny (Cinq-Mars), Victor Hugo (Quatrevingt-Treize), Rene de Chateaubriand (Martyrs), Charles Dickens (A Tale of Two Cities), Leo Tolstoy (War and Peace), and, of course, James Fenimore Cooper with his saga The Leather-Stocking Tales.

The Last of the Mohicans (1826) is the second of a pentalogy which became an immediate success. The book is a monument of American literature. Even those who have not heard of James Fenimore Cooper (1789-1851) may know something of the novel and may take its title as a reference to the passing of a heroic generation and era. The novel's subtitle, "A Narrative of 1757", indicates that the events date back to the turbulent time during the French and Indian War of 1754-63. The novel is brimmed with graphic descriptions of many characters and many life-and-death conditions. Cooper talks, among many things, about the Indian removal and miscegenation, and points to the notion of nations in conflict. The Last of the Mohicans was very influential in shaping national consciousness in settler colonies, and it would not be wrong to say that, in this novel, Cooper created a frontier mythology for post-colonial American nationalism. This paper examines Cooper's The Last of the Mohicans in order to disclose the underlying discourse of race and nationhood. The paper will focus on Cooper's idea of historical transformation and human progress, and will reveal how the teleological, stage-by-stage passage of history from savagery to civilization, from tribal communities to a unified nation, empowered by cultural appropriation, resulted in the formation of a fresh and hybrid American national identity.

\section{Politics of 'Nation(-hood)'}

Nation is a spatial/temporal phenomenon, which has developed over time and through history. It refers to a large group of people strongly bonded together mainly on the basis of common ancestry, language, and land, sharing one destiny and a unique national identity. This is the connective aspect; however, nation has a dis-connective aspect too: 
"Throughout history, humans have formed groups of various kinds around criteria that are used to distinguish 'us' from 'them'. One such group is the nation" (Grosby 2005: 1). This implies that the people who live in a certain geographical zone tend to see themselves as a community quite different with the people from other areas. Being so, is this an allagreed definition of the word 'nation'?

In 1882, the French Orientalist Ernest Renan addressed his audience at the Sorbonne in a monumental lecture entitled "What Is a Nation?" He emphasized the historical beginnings of the idea of a nation, and traced the emergence of the nation-states to the devastation of the classic and medieval empires; "Nations . . . are something fairly new in history. Antiquity was unfamiliar with them" (in Bhabha 1990: 9). To Renan, nations were totally unstable formations. In this sense, nations are not 'natural' entities'; hence, it always lays open the possibility of its breaking-up and retreat back into the subdivisions of 'tribe'. This is merely the inevitable consequence of its vulnerable nature as a social construct.

Leela Gandhi believes that the unquestionable legitimacy of nationalism is attained through its labor on behalf of modernity. Also, other theorists such as Ernest Gellner and Benedict Anderson - in particular-defend nationalism as the sole form of political organization that can match the social and intellectual condition of the modern world. Gellner argues that nationalism of any modern sort emerged out of the shift to industrial era. He believes that in pace with drastic changes in the forms of social organization - as they become more and more complicated day by day-the economic operations of time decree a somewhat unified discourse:

[. . .] mobility, communication, size due to refinement of specialization-imposed by the industrial order by its thirst for affluence and growth, obliges its social units to be large and yet culturally homogenous. The maintenance of this kind of inescapable high (because literate) culture requires protection from a state. . (Gellner, quoted in Gandhi 1998: 104).

This particular idea and many others that have been posited in the same vein may reveal a movement of time and history, which is linear and has a telos: the progression from the so-called 'Dark' Ages towards the light of modernity. This genealogically-informed view has been dominant since — at least - the Enlightenment, and was strengthened via theories of Hegel and, later, of Marxists. However, as Terry Eagleton has observed, nationalism does involve "an impossible irony", being itself a "form of alienation" it cancels the particularity of individuals (Eagleton et al. 2001: 23). Eagleton believes "nationalist struggle [is] necessarily caught up in the very metaphysical categories it hopes finally to abolish" (Ibid. 24). For instance, Cooper uses the image of the Native American "as a symbol of America's separation from its European beginnings" and thus as an "important answer to the American quest for national identity" (May 2011: 171). However, these same redskins who were once representative of America's separation from its European beginnings ought to be contained later in the dominant white ideology. This idea provides an answer to the question of nation as problem and/or possibility. Therefore, we should believe in this idea that nationalism is a twosided coin, a Janus-like figure of patriotism and xenophobia. Of course, for Cooper-who was influenced by Sir Walter Scott who was himself influenced by the literati of the Scottish Enlightenment who regarded history as a site of cultural change and evolution - these conflicts might be justified for constituting "necessary, organic components of evolution [...] embodying the dialectics of historical development” (Lukács 1989: 28).

\subsection{Clash of Cultures}

Cooper opens The Last of the Mohicans in a nostalgic tone, with two old friends talking in the forests where the French and Indian War is being fought. They are talking about their forebears. They emphasize the difference and the animosity between Indians and the white;

Your fathers came from the setting sun, crossed the big river, fought the people of the country, and took the land; and mine came from the red sky of the morning, over the salt lake, and did their work much after the fashion that had been set them by yours. (Cooper 1989: 24)

Chingachgook continued talking about his free past and the happiness of that time. However, paradise faded with the arrival of the white man:

We were one people and happy. . . . The Dutch landed, and gave my people the fire-water; they drank until the heavens and the earth seemed to meet, and they foolishly thought they had found the Great Spirit. Then they parted with their land. (Ibid. 27)

Chingachgook refers to the unwelcome but inevitable blending of European and native cultures. This clash of two different cultures is very significant and is much emphasized upon because it shows that nation is not only a zone of conflict but also a site of hybridization, negotiation and, hence, of transformation.

The role of the past in shaping the future sets the tone for the rest of the novel. Throughout the novel, both Hawkeye and the reader are presented with a series of tensions and conflicts related to language, culture, race, and land. Following the Romantic form perfected by Sir Walter Scott (1771-1832), ${ }^{i}$ Cooper set his mind to make use of historical settings in sheer order to highlight conflicts, tensions, and ultimate resolutions between moral, racial, and cultural opposites. He tried - again, similar to Scott - to create characters who attempt to "find a middle way between the warring extremes" (Lukács 1989: 32, emphasis added), the "colonizing capitalism of France and England" and their fight over suppressing the "gentile society of the Indians" (Ibid. 64). And this inevitable (Hegelian) progress of history to a "higher level (aufgehoben)" had tragic afterbirth: decline of the indigenous Redskins. ${ }^{\text {ii }}$

\subsection{Language}


The Hegelian idea of inevitable historical progress - which is repeated in Lukács' The Historical Novel-is also visible language-wise. Steven Blakemore has made an interesting observation in "Strange Tongues: Cooper's Fiction of Language in The Last of the Mohicans" (1984); he refers to Cooper's use of two linguistic paradigms of 'fallen' (the pre-lapsarian) and 'unfallen' (post-lapsarian) languages, "the Edenic language of the Delawares and the fallen languages of the French and English" (21) ${ }^{\text {iii }}$ Therefore, the coming of Europeans to America led to disappearance of "Ur-mother tongue of all Indian dialects" which was believed to be Edenic and unfallen (Ibid. 21); hence, the expropriation of language is the first step to expropriation of the land. However, Cooper intimates that this 'corruption' of language and land was not only unavoidable but required, for it ensures - though in a strange way - the progress of human civilization. Similar to Scott (especially in Waverley), Cooper tries to show that the birth and development of a young, unified nation is predicated on subsuming (or, if necessary, subduing) Natives. In the course of this progress, even the Indians are induced (or forced) into fighting in white, European wars.

\subsection{Race}

Cooper was writing, mainly, for a white audience; that is why there seems to be a strong tendency to differentiate between the races and cultures throughout the novel. Cooper describes the major characters in racial terms, endowing them with physical and personal traits which are directly linked to their race; however, we know the firm advocacy of one's race and culture may lead to separatism. Hawk-eye frequently announces, "I am genuine white" with "no cross in his blood"- "a white man without a cross" (Ibid. 86). Likewise, Chingachgook, arguing that he is an unmixed man, calls his son Uncas "the last of the Mohicans". This tribal separatism is so firm as to make Hawk-eye iterate, "a Mingo is a Mingo and God having made him so, neither the Mohawks nor any other tribe can alter him" (Cooper 1989: 36). Later he says, "as for me, who am of the whole blood of the whites, it is befitting that I should die as becomes my color" (Ibid. 83). Another example is Magua; he is introduced as swarthy, a savage with "an air of neglect about his person" and a "sullen fierceness mingled with the quiet of savage" (Ibid. 14). Where Uncas is handsome, unmarked, and of pure blood, Magua is repulsive in appearance and tainted in blood; they-respectively-represent noble and ignoble savage. While Uncas is not tainted by contact with Europeans, Magua is the horror of European colonial suppression.

The Munro sisters are also distinguished by race. Alice has "a dazzling complexion, fair golden hair and bright blue eyes," which is in sheer contrast with her sister Cora, with her "dark eye" and "tresses . . . shining and black, like the plumage of the raven" (Ibid. 11). Cora, the old sister, is later identified as the daughter of a West Indian mother while Alice, the younger, was born to a woman of native Scotland. Alice is portrayed as a beauty, "her soul is pure and spotless as her skin!" The facial beauty and whiteness is generalized to be applied to spiritual beauty. On the other hand, Cora is identified by her "raven tresses". She is called "the dark-hair" by Uncas. This emphasis on darkness will come to foreshadow her dark, tragic destiny. She is a tragic mulatto. She was born in the West Indies or Caribbean. Her mother was "descended, remotely, from that unfortunate class, who are so basely enslaved" (Ibid. 178).

Similar to Scott's Waverley and Ivanhoe, Cooper's novel dichotomizes fair/dark heroines, with fair heroine representing European civilization and dark one representing mixed blood and 'obscured worth'. Consequently, marriage of Cora and Uncas "would be impossible in Cooper's world of civilization and progress; hence, temporizing the issue by making Cora's ancestry somewhat dubious, he must do away with them both" (Pearce, qtd in Mills 1986: 446). That is why Cora and Uncas must both die. Perhaps Cooper believed that through this racial delineation he could sketch a homogenous Utopia in the New World and pray for its realization; however, he was unaware of the ambivalence that haunts any essentialist approach to nation - the uncanny persistence of the minorities as performative historical subjects. ${ }^{\text {iv }}$

\subsection{Whose Side Are You On? Diaspora, Liminality, and Hybridity}

In cultural and postcolonial studies, 'diaspora theory' is a pivotal issue. From the Greek word 'diaspeir', diaspora comes to denote 'scattering/dispersing'. Diaspora, therefore, refers to the voluntary or involuntary movement of people from their mother lands into a new geographical space. Colonialism ${ }^{v}$ itself was a diasporic phenomenon that led to the dispersion of millions of people around the world. Most of the emigrants might have felt the diasporic experience though we know diasporic experience is not the same as emigration. Diasporic experience is somewhat bitter, for its subject will always feel a sense of 'in-between-ness', a liminal condition.

In this section we are going to discuss such a diasporic experience in the character of Cora, Munro's eldest daughter. Diasporic subjects are more often marginalized; they are caught in the binary of center/periphery. The people on the margin are always minorities and would remain in the same situation. The dominant ideology will endow them with the illusion of living in a unified nation, but an illusion will remain an illusion. Cora is doomed to die, to be removed from the future nation. Here we would like to bring into comparison Cora's experience with what happened to Flora MacIvor and Rebecca in Sir Walter Scott's Waverley and Ivanhoe, respectively. Though both are characters of moral integrity, they are doomed to live in an 'unhomely' state-living on the borders. They belong to the lowest level of society. The essentialist way of thinking that tends to privilege the so-called pure race and nationality (if at all such an idea exists in actuality) over hybridity will never allow a character like Cora-though extremely helping - to gain access into the center of the nation. Although it may not be a conscious act, the mere practicing it will reveal the underlying desire of the dominant to keep the voice of the suppressed unheard.

Today, the ideas of 'in-between-ness' and hybridity are of increasing importance in postcolonial studies. According to Homi K. Bhabha (1949- ), every culture is hybrid and, thus, no pure culture is to be found. Generally speaking, the 
concept of hybridity is central to the novel's thematic explorations of race and family. Hybridity refers to the creation of a new 'third space' which is transcultural. Moreover, hybridity is not limited to race. It can take many other forms: cultural, linguistic, etc. Linguistic hybridity may refer to multivocal narratives. We can trace multivocality in the sheer use of different languages by different tribes within a nation. In the case of cultural hybridity we may focus mainly on the characters of Cora and Hawkeye who bear lineages of different cultures.

Cora is a hybrid character because her mother was black and her father white, symbolizing both colonizer and colonized. Many of the other characters are either symbolically or actually 'crossbred', and the results are never shown to be positive. Cora's mother is a woman of West Indian slave origin, and though Colonel Munro takes great pride in his daughter's heritage, it is clear that he expects it to retard her progress through life. Cora's mixed blood is a signifier of cultural blending. Even her father reserves the pure-bred Alice for Heyward.

Hawkeye is also a hybrid character because he is white by blood and Indian by his way of life. He bridges the separate worlds of the Indians and the whites. He proudly says that he has no Indian blood, and yet, at the same time, he wears Indian shoes and garments, frequents the company of Indians, and wanders restlessly over border after border. Bhabha's concept of 'unhomeliness' is visibly manifest in his condition. Thus while Hawkeye is, as he insists to a hyperbolic degree, a "man without a cross", he is at the same time the man who is of both and neither cultures. He is a telling example of an in-between character. However, these hybrids are 'cultural negotiators' who "would secure a future free of xenophobia"; therefore, the future hybrid society would create "a new social order through the principle of synthesis and combination of differences" (Papastergiadis, in Werbner \& Modood 1997: 261).

All in all, the future nation would be a hybrid one, because "hybridity is the 'third space' which enables other positions to emerge. This third space displaces the histories that constitute it, and sets up new structures of authority, new political initiatives, which are inadequately understood through received wisdom (Bhabha, qtd. in Huddart 2006: 85). Cooper depicts this hybridization as a necessary rite of passage for the construction of a new America.

\section{Conclusion}

Known as 'the American Scott', James Fenimore Cooper followed the road taken by his literary paragon in writing historical novels with the aim of nation formation. The Leather-Stocking Tales generally evokes a traumatic past, and reflects Cooper's awareness of early American national identity, and this article was an attempt to examine the concepts of race and nationality in one of the classics of this American frontier saga, The Last of the Mohicans. Indeed, through a re-examination of the traces of the past, Cooper forges a path to the future: by way of re-writing the fall of Fort William Henry (prior to American independence), Cooper conveys his idea of the process of historical change and human progress. In this context, the decline of Indian natives and European settlers was ineluctable (and even necessary) because it consequently led to the rise of American nationhood. This study tried to show how much the discourse of nationhood in the novel is concealed by the dominant façade of romance, however, a careful examination of the deeper levels reveal the underlying narrative of the development of American racial identity.

Nation in Cooper's novel is a zone of cross-cultural and racial contact and although the narrator conveys a sense of fear for racial miscegenation, the hybridity is inevitable. Overall, the performativity of the discourse of nation makes boundaries unstable and ultimately prepares the ground for trans-culturization.

\section{References}

Anderson, B. (1991) Imagined Communities: Reflections on the Origin and Spread of Nationalism. London: Verso.

Ashcroft, B. and P. Ahluwalia (2001) Edward Said. New York: Routledge.

Bhabha, H. K. (1990) Nation and Narration. London and New York: Routledge.

Bhabha, H. K. (2004 [1994]) The Location of Culture. London: Routledge.

Blakemore, S. (1984) "Strong Tongues: Cooper's fiction of Language in The Last of the Mohicans", Early American literature, vol. 19, No. 1, pp. 21-41.

Cooper, J. F. (1989) The Last of the Mohicans. New York: Bantam Dell.

Eagleton, T., et al. (2001) Nationalism, Colonialism and Literature. With an introduction by Seamus Deane. Minneapolis and London: University of Minnesota Press.

Gandhi, L. (1998) Postcolonial Theory: A Critical Introduction. New York: Columbia University Press.

Grosby, S. (2005) Nationalism: A Very Short Introduction. Oxford and New York: Oxford University Press.

Huddart, D. (2006) Homi K. Bhabha. London and New York: Routledge.

Lukács, G. (1989) The Historical Novel. Trans. Hannah and Stanley Mitchell. London: Merlin Press.

May, C. T. (2011) “The Romance of America: Trauma, National Identity, and the Leather-Stocking Tales”, Early American Studies, Vol. 9, No. 1, pp. 167-186.

Mills, C. H. (1986) "Ethnocentric Manifestations in Cooper's Pioneers and The Last of the Mohicans", Journal of Black Studies, vol. 16, No. 4, pp. 435-449.

Said, E. W. (2000) Reflections on Exile and Other Essays. Cambridge, Massachusetts: Harvard University Press. 
Werbner, P. and T. Modood (eds.) (1997) Debating Cultural Hybridity: Multi-Cultural Identities and the Politics of Anti-Racism. London and New Jersey: Zed Books.

\section{Notes}

i Georg Lukács believes, "Scott had only one worthy follower in the English language who took over and even extended certain of the principles underlying his choice of theme and manner of portrayal, namely the American, Cooper. In his immortal novel cycle The Leather Stocking Saga Cooper sets an important theme of Scott, the downfall of gentile society, at the center of his portrayal" (Lukács 1989: 64).

ii Also, notice the symbolic description of sunrise and sunset in the selected passage from the novel (which is quoted above) when Chingachgook and Hawkeye are talking about their forebears and origins. Considering the Hegelian view of the passage of civilization from the East (where the sun rises) to the West (when the sun sets), Cooper's symbolic description makes more sense.

iii According to Steven Blakemore, "Cooper traces the myth of a prelapsarian language to its postlapsarian end in Babel. In fact, the Delaware village becomes the very model of Babel as the strange tongues of French, English, and Huron resound through its once sacred grounds. ... [Cooper] already saw the fall of the Indian world and the correspondent rise of white civilization" (Blakemore 1984: 36).

4 "As long as the concepts of purity and exclusivity have been central to a racialized theory of identity, hybridity has, in one way or another, served as a threat to the fullness of selfhood" (Papastergiadis, in Werbner \& Modood 1997: 257).

5 "The clash of cultures that colonialism invariably provoked, rather than producing a neat bifurcation between colonizer and colonized, encouraged the formation of new cultural hybrids" (Papastergiadis, in Werbner \& Modood 1997: 264). 